\title{
IMPACT OF ENVIRONMENTAL CONDITIONS AND AGRO- TECHNICAL FACTORS ON GROUND BEETLE POPULATIONS IN ARABLE CROPS
}

\author{
VIRIĆ GAŠPARIĆ, H. - DRMIĆ, Z. - ČAČIJA, M. - GRAŠA, Z. - PETRAK, I. - BAŽOK, R. \\ - LEMIC, D.*
}

University of Zagreb Faculty of Agriculture, Department of Agricultural Zoology, Svetošimunska 25, 10000 Zagreb, Croatia

(phone: +385-1-2393-804)

*Corresponding author

e-mail:dlemic@agr.hr

(Received $15^{\text {th }}$ Nov 2016; accepted $7^{\text {th }}$ Mar 2017)

\begin{abstract}
Ground beetles (Coleoptera: Carabidae) are the largest family of adephagan beetles. Their role in natural pest control is important due to their predatory polyphagous nutrition and bioindicative value since they are sensitive to environmental and anthropogenic changes. Therefore, the main objectives were to understand how common arable cropping systems in Croatia affect ground beetles abundance in respect to the environmental conditions. We hypothesized that environmental specifics (soil type and structure, climatic conditions) together with cultivation measures (tillage and insecticide application) would affect ground beetle activity and abundance. The research was conducted in two locations Lukač, Virovitica - Podravina County and Tovarnik, Vukovar - Sirmium County. Ground beetles were collected weekly, from May to September 2015, by epigeic pitfall traps and endogeic perforated probes from fields sown with typical arable crops in these areas. In total, 2,582 ground beetle individuals were collected using epigeic traps, and 323 ground beetles were collected using endogeic traps. Significantly lower ground beetle abundance has been recorded in Tovarnik than in Lukač. The crop and cropping history affect the abundance through modification of environmental conditions (soil characteristics, microclimate factors such as temperature and humidity), as well as trough disturbance factors such as tillage schedules and harvest/sowing schedules.
\end{abstract}

Keywords: carabids, agro-technical measures, environment, plant cover, abundance

\section{Introduction}

Ground beetles (Coleoptera: Carabidae) with over 40,000 species are the largest family of adephagan beetles (Lövei and Sunderland, 1996) inhabiting arable crops all over the world (Kromp, 1999). They are often used in cultivation experiments because they are one of the most abundant and diverse groups overwintering within cultivated fields (Holland and Reynolds, 2003). Ground beetles are bioindicators of agroecosystems quality (Cole et al., 2002; O'Rourke et al., 2008) and can be good ecological indicators of environmental change (Thiele, 1977; Maelfait, 1990). In term of environmental quality, arable land presents an anthropogenically influenced, unstable and devastated biotope with low contribution to farmland diversity (Baranová et al., 2013). Environmental change can cause a different kind of effects on the indicator species, including physiological changes or changes in species number and abundance (Raino and Niemelä, 2003). Increase or decrease of ground beetle abundance might be directly caused by the change in many abiotic and/or biotic factors (Blake et al., 1996). These factors include temperature and humidity (Lövei and Sunderland, 1996), soil characteristics, land heterogeneity and agricultural measures such as tillage, crop type, 
fertilization regimes, crop rotation and pest control (Stassart and Grégoire-Wibo, 1983; Kromp 1999; O'Rourke et al., 2008; Kos, 2010; Asteraki et al., 1992; 1995).

A further decisive factor for habitat selection considering soil specifics is soil particle size distribution (Thiele, 1977; Meissner, 1984). Vician et al. (2015) stated that content of organic matter and $\mathrm{pH}$ are the most significant factors that influence ground beetle diversity and abundance in agroecosystems. Some aspects of landscape heterogeneity (e.i. field size (Kromp, 1999), non-cropped habitat (Pollard, 1968; Sotherton, 1985) and land use diversity (Östman et al., 2001)), will also influence the ground beetles communities (Chapman, 2014).

Stassart and Grégoire-Wibo (1983) stated that depth of tillage is one of the major factors affecting ground beetle field fauna. Dobrovolsky (1970) and Baguette and Hence (1997) reported that deep cultivation had a detrimental effect on ground beetle abundance. Opposite to that, Cárcamo (1995) and Weibull et al. (2003) trapped significantly more ground beetle individuals under intensive tillage compared with reduces tillage.

Arable crops can affect ground beetles through modification of microclimatic factors, and trough disturbance factors (harvest and tillage schedules; Thiele, 1977; Witmer et al., 2003; O'Rourke et al., 2008). Although no ground beetles appear to be strictly related to certain crops, some studies reported a general difference between ground beetle abundance distributions in winter cereal versus root crops (beets) (Kromp, 1999). In root crops, the long period of bare soil in early spring present extreme soil-surface microclimate which has a negative influence on ground beetle abundance. In winter cereals, the less extreme microclimate is established in early spring and creates positive conditions for many ground beetle species (Kromp, 1999). Also, ground beetle abundance can be influenced by the crop-dependent timing of cultivation measures. Spring tillage and insecticide treatments can affect ground beetles at the beginning of their activity, but also, autumn tillage and insecticide treatments can disturb ground beetles overwintering (Hence et al., 1990).

However, the effects of soil tillage could not be clearly separated from the effects of different fertilization regimes (e.g. manure, mineral fertilizers) and may also vary with the crop, and among localities. Pietraszko and De Clercq (1982) and Hence and Grégoire-Wibo (1987) revealed organically manured fields to have higher ground beetle diversity and abundances. Similar results were reported by Bažok et al. (2007) and by Kos et al. (2011) in Croatian conditions. Kromp (1990) showed that the ground beetle abundance and diversity significantly decreased in the fields with the high amount of nitrogen applied as mineral fertilizer, manure and liquid manure.

The population of ground beetles in the agricultural landscape can be also influenced by the chemical pest control (Varvara et al., 2012). Basedow (1987) investigated ground beetle populations in winter wheat fields and found a significant decrease of ground beetles density as a consequence of intensive insecticide application against cereal aphids. Opposite results were established by Kos et al. (2010) who did not find significant differences in ground beetle abundance between treated and untreated fields. Negative effects of insecticides on ground beetles were recorded by Asteraki et al. (1992; 1995). Douglas et al. (2014) shown that insecticides (e.g. thiametoxam) can be poisonous to ground beetles due to their predatory nature. This means that chemical treatment of some agricultural pests can also affect ground beetles that consumed them (Jeschke et al., 2011; Szczepaniec et al., 2011). 
In this study, the main objectives were to understand how common arable agroecosystems affect ground beetles populations in respect to the environmental conditions. We hypothesized that, within a region, environmental specifics (soil type and structure, climatic conditions) together with cultivation measures (tillage, insecticide application) would affect ground beetle activity and abundance. To test this hypotheses we compared ground beetle abundances and population dynamics in different arable agroecosystems in two different management regions.

\section{Materials and methods}

\section{Sample sites}

Ground beetles were collected during the arable crop growing season 2015 in two different counties of Croatia representing two distinct climatic and edaphic areas: Lukač (Virovitica - Podravina County) and Tovarnik (Vukovar-Sirmium County). In each county four fields with different cropping history were chosen for ground beetle trapping. The fields were chosen to represent common cultivation and crop rotation practices as well as the agro-technical measures in both areas. Since the soil type and soil characteristics differ between locations, the tillage is adapted to the given conditions. In Virovitica - Podravina County soils contain a great amount of fine sand and coarse silt which requires conservation tillage. This means that autumn ploughing on a depth of $20-25 \mathrm{~cm}$ is followed by the furrow closure for moisture conservation in spring. In Vukovar - Sirmium County soil contains a great amount of clay which requires deeper autumn mouldboard ploughing $(30-35 \mathrm{~cm})$. Chisel ploughing and tillage with the rotary harrow in spring and after harvest are usually followed by disk harrowing and again chisel ploughing. Characteristics of sample sites are introduced in Table 1 .

\section{Climatic and edaphic factors}

Climate data used in this study (i.e., mean weekly air temperature, mean weekly soil temperature and the total amount of rainfall per week) were obtained from the Croatian Meteorological and Hydrological Service for the sampling period and analyzed per field site for period from May to September, 2015 (19th to 38th week of the year). From the fields at investigation area, soil samples were taken from the depth of a plow layer (30 $\mathrm{cm}$ ) and regional physical and chemical soil properties have been analysed. Performed pedological procedures are explained in details in Kozina et al. (2015). Plant abundance is measured by plant cover, i.e., the relative projected area covered by a species (Kent and Coker, 1992). In our study, we used data from Kisić et al. (2005) about the percentage of plant cover, which are characteristic for part of Croatia where our study was conducted. 
Table 1. General information about fields where research has been conducted

\begin{tabular}{|c|c|c|c|c|c|c|c|c|}
\hline \multirow[b]{2}{*}{ Field label } & \multicolumn{3}{|c|}{$\begin{array}{c}\text { Lukač } \\
\text { (Virovitica-Podravina County) }\end{array}$} & \multicolumn{5}{|c|}{$\begin{array}{c}\text { Tovarnik } \\
\text { (Vukovar-Sirmium County) }\end{array}$} \\
\hline & OL & $1 \mathrm{~L}$ & $2 \mathrm{~L}$ & $3 \mathrm{~L}$ & OT & $1 \mathrm{~T}$ & $2 \mathrm{~T}$ & $3 \mathrm{~T}$ \\
\hline Crop type & sugar beet & wheat & maize & oilseed rape & sugar beet & maize & wheat & wheat \\
\hline $\begin{array}{c}\text { Bare soil } \\
(\text { mth })^{*}\end{array}$ & 9 & 1 & 8 & 2 & 7 & 6 & 2 & 2 \\
\hline Fertilization & $\begin{array}{l}85 \mathrm{~kg} \mathrm{~N} \\
105 \mathrm{~kg} \mathrm{P} \\
135 \mathrm{~kg} \mathrm{~K}\end{array}$ & $\begin{array}{l}168 \mathrm{~kg} \mathrm{~N} \\
60 \mathrm{~kg} \mathrm{P} \\
90 \mathrm{~kg} \mathrm{~K}\end{array}$ & $\begin{array}{l}120 \mathrm{~kg} \mathrm{~N} \\
52 \mathrm{~kg} \mathrm{P} \\
52 \mathrm{~kg} \mathrm{~K}\end{array}$ & $\begin{array}{l}74 \mathrm{~kg} \mathrm{~N} \\
60 \mathrm{~kg} \mathrm{P} \\
90 \mathrm{~kg} \mathrm{~K}\end{array}$ & $\begin{array}{c}123 \mathrm{~kg} \mathrm{~N} \\
52 \mathrm{~kg} \mathrm{P} \\
228 \mathrm{~kg} \mathrm{~K}\end{array}$ & - & $82 \mathrm{~kg} \mathrm{~N}$ & $101 \mathrm{~kg} \mathrm{~N}$ \\
\hline $\begin{array}{l}\text { Insecticide } \\
\text { treatment }\end{array}$ & $\begin{array}{l}\text { Imidacloprid } \\
\text { (seed } \\
\text { treatment) }\end{array}$ & $\begin{array}{l}\text { Lambda- } \\
\text { cyhalothrin } \\
\text { (foliar } \\
\text { treatment) }\end{array}$ & - & $\begin{array}{l}\text { Thiacloprid } \\
\text { (foliar } \\
\text { treatment) }\end{array}$ & $\begin{array}{c}\text { Imidacloprid+ } \\
\text { Thiamethoxam } \\
\text { (seed treatment) } \\
\text { Lambda- } \\
\text { cyhalothrin x2 } \\
\text { (foliar treatment) } \\
\text { Cypermethrin + } \\
\text { Chlorpyrifos } \\
\text { ethyl } \\
\text { (foliar treatment) }\end{array}$ & ) & $\begin{array}{l}\text { Lambda- } \\
\text { cyhalothrin } \\
\text { (foliar } \\
\text { treatment) }\end{array}$ & $\begin{array}{l}\text { Lambda- } \\
\text { cyhalothrin } \\
\text { (foliar } \\
\text { treatment) }\end{array}$ \\
\hline $\begin{array}{l}\text { Pre-crop } \\
(2014)\end{array}$ & wheat & sugar beet & wheat & wheat & soybean & sugar beet & sunflower & sunflower \\
\hline $\begin{array}{l}\text { Pre-crop } \\
\text { (2013) }\end{array}$ & sunflower & maize & sugar beet & sunflower & wheat & wheat & sugar beet & barley \\
\hline $\begin{array}{l}\text { Pre-crop } \\
\text { (2012) }\end{array}$ & maize & maize & fallow & sugar beet & sugar beet & sunflower & wheat & sugar beet \\
\hline
\end{tabular}

*number of months when fields were not covered after harvesting (in 2014) till soil preparing for crops which was grown in 2015 vegetation season 


\section{Ground beetle trapping}

Epigeic covered pitfall traps and endogeic perforated probes were used to collect adult ground beetles. On each of four fields on both locations four pitfall traps and four perforated probes (WB PROBE II ${ }^{\circledR}$ Trap, Trece inc.) were placed. Polythene pots $(\varnothing=12 \mathrm{~cm}, \mathrm{~h}=18 \mathrm{~cm})$ were incorporated $18 \mathrm{~cm}$ into the soil and covered with PVC roofs $(\varnothing=16 \mathrm{~cm})$ approximately $2-4 \mathrm{~cm}$ above ground level. Four pitfall traps were placed into the center of the each field at $50 \mathrm{~m}$ apart and $100 \mathrm{~m}$ away from the field edges to minimize the edge effect on ground beetle catches. Each trap was half filled with salted water (20\% solution) for captures conservation, with the addition of few drops of detergent to reduce the surface tension (no other chemicals were added). Trapping was performed from the 19th to the 38th week of the year. Perforated PVC probes were placed at $10 \mathrm{~m}$ distance from each pitfall traps and also inspected once a week. During weekly observation period, all ground beetles caught were collected from the traps and counted. For identifying ground beetles following keys were used: Auber, 1965; Bechyne, 1974; Harde and Severa, 1984).

\section{Data analysis}

Meteorological data (mean air temperature, mean soil temperature and the total amount of rainfall), the physical and chemical properties of the soil, and the average number of collected ground beetles were analyzed by a one-way analysis of variance (ANOVA; Gylling Data Management, Inc., USA, ARM 9® GDM software, Revision 9.2014.7.). A Tukey's posthoc test was used to establish climatic and edaphic differences among the fields and between the investigated areas. Where appropriate, data were $\sqrt{ }(x+1)$ transformed. The ground beetle trapping results using both endogeic and epigeic traps for the selected intervals are presented as a mean number of individuals caught per field per week as a function of percent of ground cover with culture on every field. Ground beetle population dynamic results for the selected intervals are presented as the total number of ground beetles caught per traps (epigeic and endogeic) per field per week as a function of the average weekly air temperatures $\left({ }^{\circ} \mathrm{C}\right)$, total weekly precipitation $(\mathrm{mm})$ and average weekly temperature of soil $\left({ }^{\circ} \mathrm{C}\right)$ at a depth of $10 \mathrm{~cm}$. Values were determined from $19^{\text {th }}$ to the $38^{\text {th }}$ week of the year for epigeic caches, and from $22^{\text {nd }}$ to the $38^{\text {th }}$ week for endogeic caches.

\section{Results}

\section{Climatic and edaphic factors}

The both investigated locations were classified as belonging to the Cfwbx climatic type of the Köppen classification system (Penzar and Penzar, 2000), where temperate/mesothermal climates $(\mathrm{Cf})$ with dry winters $(\mathrm{w})$ dominate. In spite belonging to the same climatic type, locations in this research differ according to the climatic conditions. Significant differences in mean air and soil temperatures occurred as did the total amount of rainfall (Table 2). Edaphic conditions differ among locations also. Significant differences in the share of fine sand, fine silt, clay and $\mathrm{pH}$ values occurred. A detailed description of the regional physical and chemical soil properties are given in Table 3. 
Table 2. Characteristics of the weather conditions prevailing in the two Croatia counties were ground beetles were sampled and corresponding ANOVA results

\begin{tabular}{cccc}
\hline County & $\begin{array}{c}\text { Mean soil } \\
\text { temperatures }\left({ }^{\circ} \mathbf{C}\right)\end{array}$ & $\begin{array}{c}\text { Mean air } \\
\text { temperatures }\left({ }^{\circ} \mathbf{C}\right)\end{array}$ & $\begin{array}{c}\text { Total amount } \\
\text { of rainfall }(\mathbf{m m})\end{array}$ \\
\hline Virovitica-Podravina & $23.40 \mathrm{~b}^{*}$ & $20.52 \mathrm{~b}$ & $492.30 \mathrm{a}$ \\
Vukovar-Sirmium & $25.22 \mathrm{a}$ & $23.50 \mathrm{a}$ & $220.00 \mathrm{~b}$ \\
HSD P $=\mathbf{0 . 0 5}$ & 0.32 & 0.23 & 118.17 \\
\hline
\end{tabular}

*means followed by the same letter are not significantly different according to the Tukey's HSD test $(\mathrm{P}<0.05)$

Table 3. Physical and chemical properties of the soil samples in two Croatia counties and corresponding ANOVA results

\begin{tabular}{cccc}
\hline $\begin{array}{c}\text { Soil } \\
\text { physico-chemistry }\end{array}$ & Virovitica-Podravina & Vukovar-Sirmium & HSD P = 0.05 \\
\hline Coarse sand & 2.35 & 1.62 & $\mathrm{~ns}$ \\
Fine sand & $11.83 \mathrm{a} *$ & $2.47 \mathrm{~b}$ & 4.583 \\
Coarse silt & 38.42 & 35.87 & $\mathrm{~ns}$ \\
Fine silt & $31.65 \mathrm{a}$ & $28.39 \mathrm{~b}$ & 2,012 \\
Clay & $15.75 \mathrm{~b}$ & $31.65 \mathrm{a}$ & 2,766 \\
Soil pH in H2O & $6.65 \mathrm{~b}$ & $7.71 \mathrm{a}$ & 0,498 \\
Soil pH in KCl & $5,58 \mathrm{~b}$ & $6.93 \mathrm{a}$ & 0.691 \\
Humus & 3.2 & 3.29 & $\mathrm{~ns}$ \\
\hline
\end{tabular}

*means followed by the same letter are not significantly different according to the Tukey's HSD test $(\mathrm{P}<0.05)$

\section{Ground beetle trapping}

In total, 2,582 ground beetle individuals were collected using epigeic traps, and 323 ground beetles were collected using endogeic traps. Generally, significantly lower ground beetle abundance on all four fields in both types of traps has been recorded in Tovarnik than in Lukač (Table 4 and 5). In the whole sampling period, only one ground beetle has been collected with an endogeic trap on one out of the four fields in Tovarnik. Although slightly higher number of ground beetles was collected in Tovarnik on the field 3T, analyzing epigeic caches no significant difference among fields was recorded (Table 4).

Table 4. The average number of ground beetles collected using epigeic traps in 20 weeks sampling period in two location of Croatia and the corresponding ANOVA results

\begin{tabular}{cccc}
\hline \multirow{2}{*}{ Fields } & \multicolumn{2}{c}{ Location } & \multirow{2}{*}{ HSD P $=\mathbf{0 . 0 5}$} \\
\cline { 2 - 3 } & Lukač & Tovarnik & $2,77 \mathrm{t}^{*}$ \\
$\mathbf{0}$ & $62,37 \mathrm{~b}^{1} \mathrm{~A}^{2}$ & $5,59 \mathrm{~B}$ & $1,99 \mathrm{t}$ \\
$\mathbf{1}$ & $67,07 \mathrm{bA}$ & $11,21 \mathrm{~B}$ & $2,03 \mathrm{t}$ \\
$\mathbf{2}$ & $108,89 \mathrm{bA}$ & $10,38 \mathrm{~B}$ & $0,595 \mathrm{t}$ \\
$\mathbf{3}$ & $356,66 \mathrm{aA}$ & $12,59 \mathrm{~B}$ & \\
\hline
\end{tabular}

*data were transformed by square root transformation of $\mathrm{X}+0.5$; mean descriptions are reported in transformed data units and are not de-transformed; ${ }^{1}$ small letters refer to differences among fields; ${ }^{2}$ capital letters refer to differences among localities 
Table 5. The average number of ground beetles collected using endogeic traps in 15 weeks sampling period in two location of Croatia and the corresponding ANOVA results

\begin{tabular}{cccc}
\hline \multirow{2}{*}{ Fields } & \multicolumn{2}{c}{ Location } & \multirow{2}{*}{ HSD P $=\mathbf{0 . 0 5}$} \\
\cline { 2 - 3 } & Lukač & Tovarnik & $\mathrm{ns}$ \\
$\mathbf{0}$ & $1,11 \mathrm{c}^{\mathrm{l}}$ & 0,00 & $\mathrm{~ns}$ \\
$\mathbf{2}$ & $2,81 \mathrm{bc}$ & 0,19 & $\mathrm{~ns}$ \\
$\mathbf{3}$ & $8,4 \mathrm{~b}$ & 0,00 & $0,385 \mathrm{t}^{*}$ \\
HSD P $\mathbf{0 . 0 5}$ & $59,04 \mathrm{aA}^{2}$ & $0,00 \mathrm{~B}$ & \\
\hline
\end{tabular}

*data were transformed by square root transformation of $\mathrm{X}+0.5$; mean descriptions are reported in transformed data units and are not de-transformed; 1 small letters refer to differences among fields; 2capital letters refer to differences among localities

At location Lukač significantly higher epigeic caches occurred on field $3 \mathrm{~L}$ comparing with other three fields. There have been no significant differences between caches on 0L, 1L and 2L fields. Similar results occurred with caches by endogeic traps (Table 5). At field 3L significantly highest abundance occurred, while at other fields differences exist but not significant. At field $0 \mathrm{~L}$ the lowest ground beetle abundance has been observed.

Generally, the highest ground beetle abundance was recorded at field 3 (sugar beet sown three years ago) on both locations using both trap methods. The lowest ground beetle abundance was recorded at field 0 (sugar beet field) on both locations (Table 4 and 5).
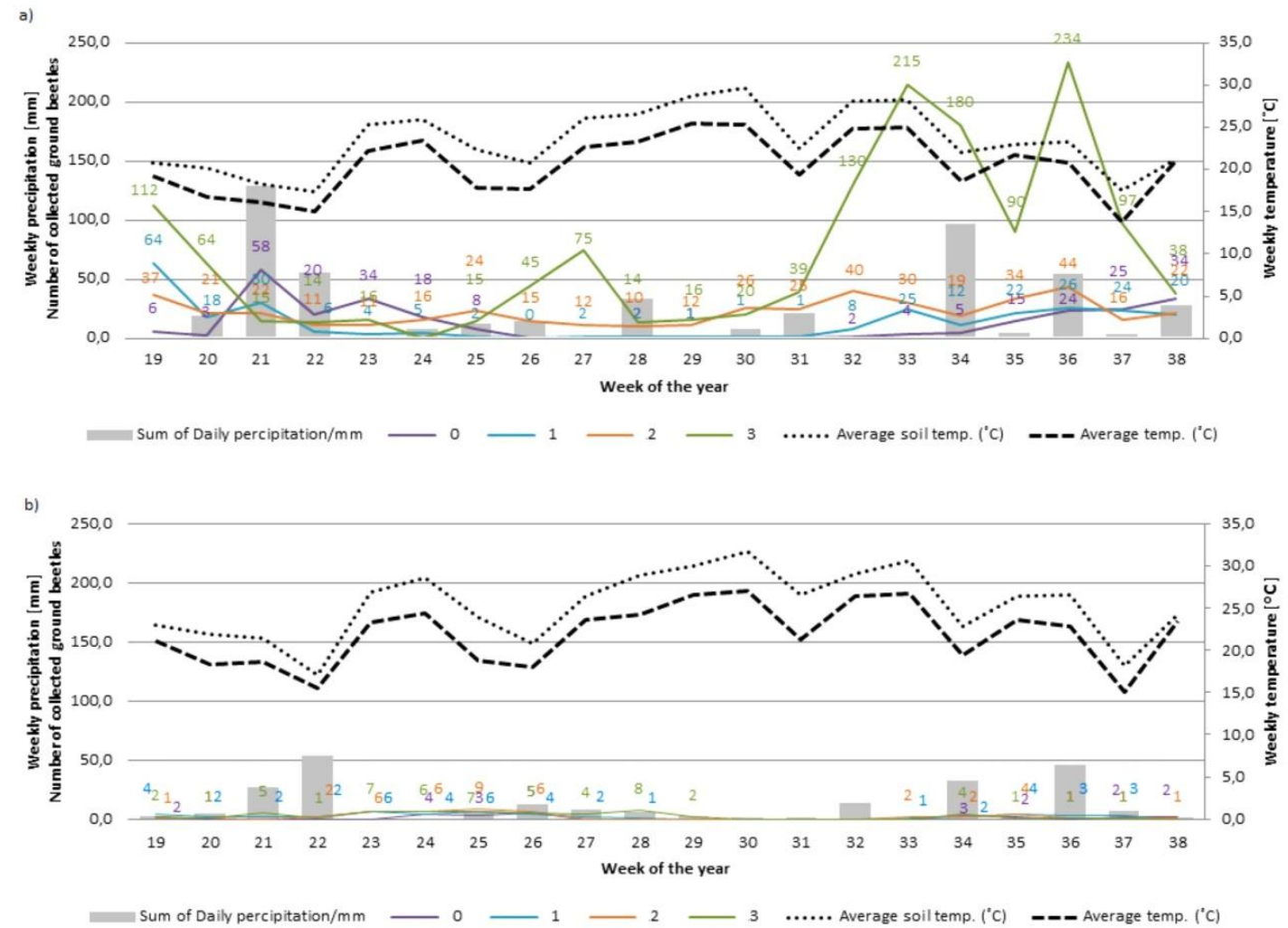

Figure 1a and b. Number of collected ground beetles per week in Lukač and Tovarnik by epigeic traps in respect to the weekly precipitation and temperature 
At location Lukač, the total number of ground beetles collected by epigeic traps per week was high at the beginning of collection period at week $19^{\text {th }}$ and lasted till week $21^{\text {st }}$. The second maximum of the population started at the $32^{\text {nd }}$ week and lasted till $36^{\text {th }}$ week (Fugure 1a). The weekly endogeic caches at location Lukač were low but with an evident increase of ground beetle caches from $24^{\text {th }}$ till $28^{\text {th }}$ week, and again at $37^{\text {th }}$ and $38^{\text {th }}$ week (Figure $2 a$ ). At location Tovarnik caches in all period were low. Slight population increase in epigeic caches was observed from $23^{\text {th }}$ till $28^{\text {th }}$ week, and again from $34^{\text {th }}$ till $37^{\text {th }}$ week (Figure $1 b$ ). Only one ground beetle was collected with endogeic trap at location Tovarnik (Figure 2b).
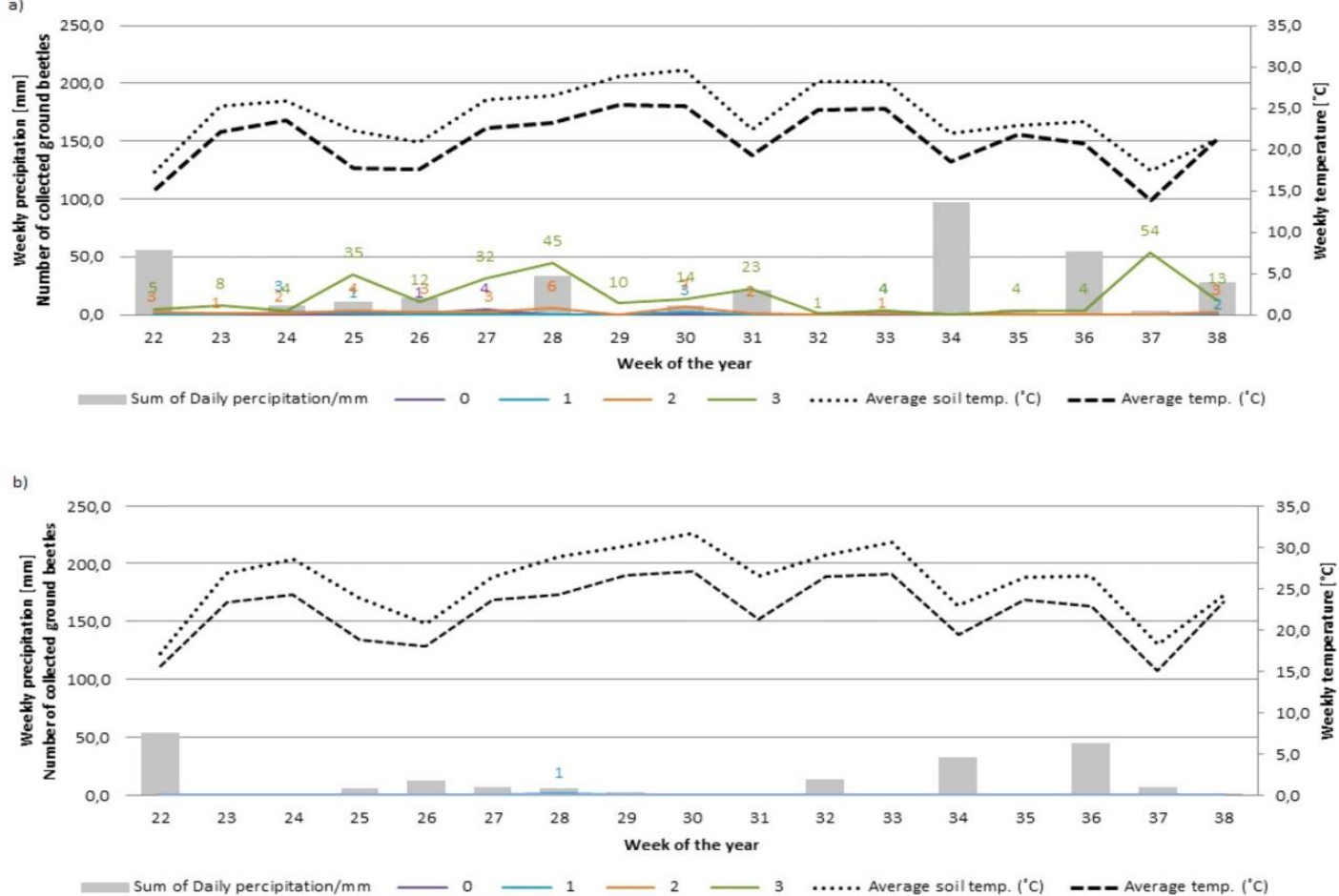

Figure 2a and b. Number of collected ground beetles per week in Lukač and Tovarnik by endogeic traps in respect to the weekly precipitation and temperature

The relationship between the number of collected ground beetles per week and percentage of plant cover in investigated period on both locations was evaluated (Figures 3 and 4). Generally, the total ground beetle caches per week were higher in winter crops which were sown in autumn previous year, comparing with sugar beet and maize which were sown in spring after long bare soil period (Figures 3 and 4). 

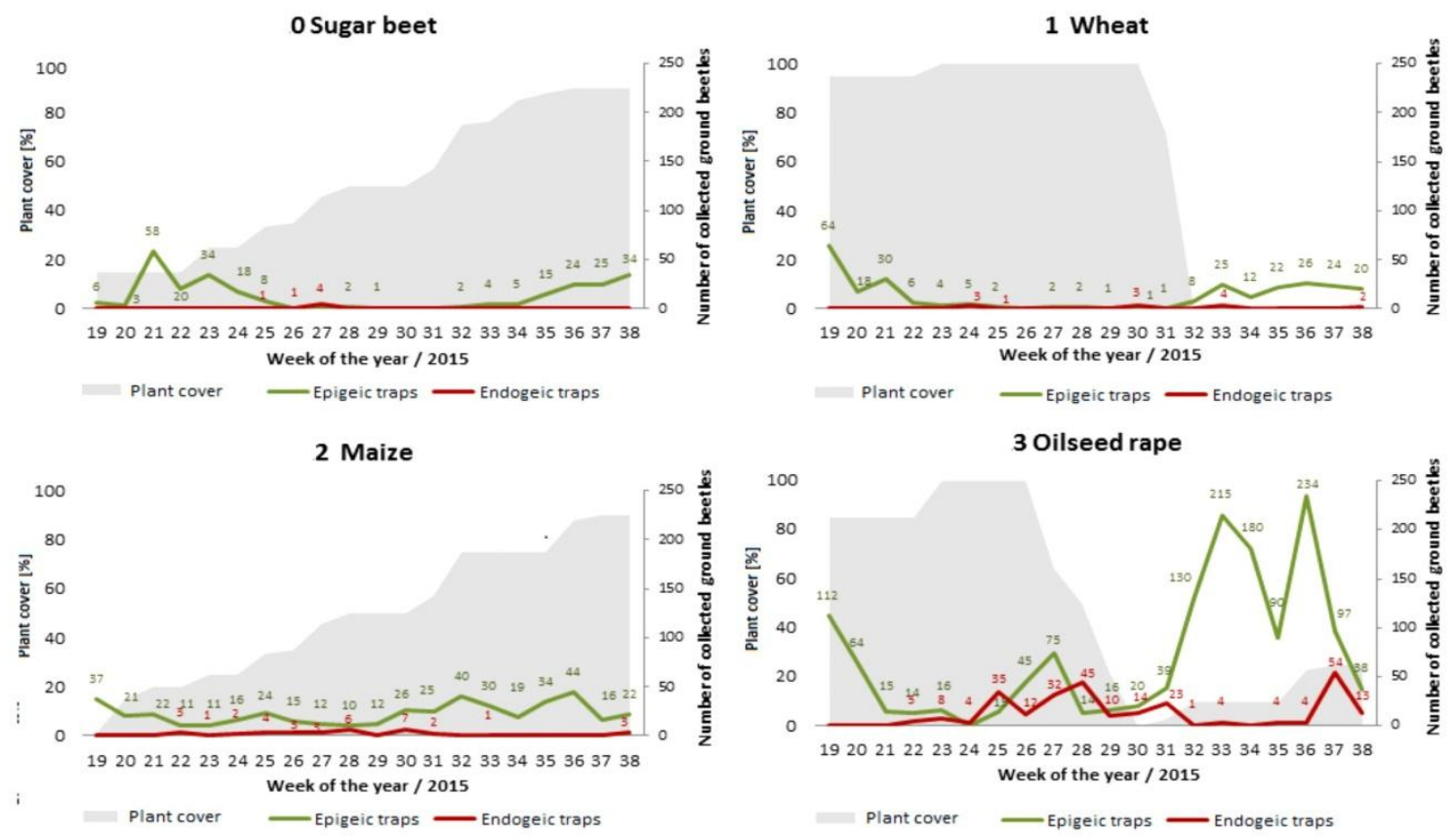

Figure 3. Ground beetle dynamics in relation to plant cover in Lukač
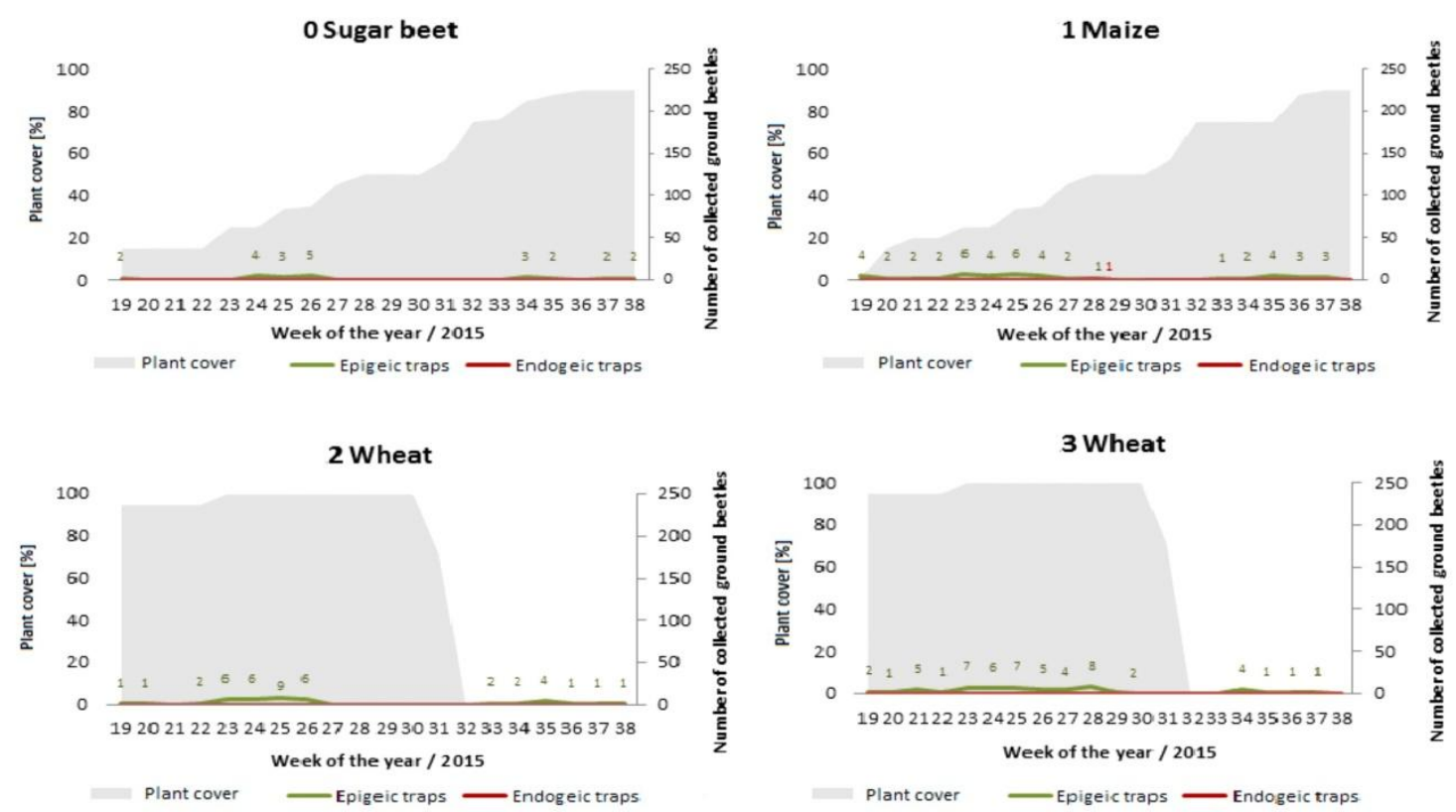

Figure 4. Ground beetle dynamics in relation to plant cover in Tovarnik

\section{Discussion}

This is the first detailed study in Croatia aimed at understanding how intensive arable crop production with their environmental and management specificities affects ground beetle communities. The abundance of the endogeic and epigeic ground beetles generally differed according to climatic and edaphic factors and specific environmental 
and cropping systems. Several key findings describe the impact of agro-ecological factors and agro-technical measures on ground beetle populations.

(i) The catches at locality Tovarnik were lower comparing to the catches at locality Lukač. The difference in the total catches between localities could be influenced by climatic conditions. Although the investigated localities are situated in the same climatic regions according to Koppen classification (Penzar and Penzar, 2000), the difference in climatic conditions during the investigation were established. At the location Tovarnik the growing season was characterized by exhibiting significantly higher mean air and soil temperatures than in Lukač (Table 2). At the location Lukač, the total amount of rainfall in the same period was significantly higher than in Tovarnik (Table 2). Presented results of ground beetle population dynamics shown that population increase follows air and soil temperature decrease. According to these information ground beetles seems to prefer humid areas and periods with lower air and soil temperatures. The ground beetle microclimatic preferences are far from uniform (Thiele, 1977) concretely, woodland species prefer dark and humid sites, whereas field species prefer warm and dry sites. Since we established higher ground beetle population at more humid and less warm locality we shall consider other factors which could influence the population level.

(ii) The difference in the total catches between localities could be influenced by edaphic conditions. Soils in Tovarnik have a significantly higher proportion of clay while soils in Lukač have a significantly higher proportion of fine sand and fine silt (Table 3). There are also differences in $\mathrm{pH}$ values between these locations. Tovarnik has neutral to slightly basic soils while Lukač has acidic to slightly acidic soils (Table 3). The content of humus on both locations was similar. Higher ground beetle abundance recorded at location Lukač is opposite to statements of previous researches (Barbercheck, 1992; Benitez et al., 2014; Hong et al. 2007; Turpin and Peters, 1971) who found that large proportion of sand could have a negative impact on larval survival. We can conclude that $\mathrm{pH}$ value and soil structure have the great influence on ground beetle abundance in our survey. According to edaphic factors prevailing at investigation areas ground beetles prefer slightly acidic soils with a great amount of fine silt and a small proportion of clay.

(iii) The intensity of ploughing was the main agro-technical difference between the studied locations so could be the cause of differences in ground beetle catches. The fields in Tovarnik were ploughed more often and on greater depth than the fields in Lukač. Ploughing is known that significantly influences psycho-chemical and biological soil properties and, along with other factors affects the abundance of various invertebrates (Vician et al., 2015). Generally, invertebrates tend to be enhanced under conservation tillage conditions because of reduced soil disturbance, increased surface residues and greater weed diversity. According to previous studies, higher ground beetle trapping rates were recorded on fields with reduced tillage or no tillage at all compared with conventionally tilled ones (House and All, 1981; Blumberg and Crossley, 1983; House and Stinner, 1983; House and Parmalee, 1985; Ferguson and McPherson, 1985; Stinner et al., 1988; Tonhasca, 1993). Presented results of this study confirm previous statements, meaning that conservation tillage, such as conducted on fields in Lukač, suit better to ground beetles survival than conventional tillage measures that are common in Tovarnik.

(iv) The soil factors are greatly influenced by weather conditions and ploughing but also are affected by crops growing at the specific area. Previous studies have shown that 
crops affect ground beetles through modification of microclimatic factors, and trough disturbance factors such as harvest and tillage schedules (Thiele, 1977; Holland, 2002). The strong effects of crops on ground beetles abundance seen in this research support the results of numerous other studies (Tonhasca, 1993; Zhang et al., 1998; Honek and Jarosik, 2000; Ward and Ward, 2001; Witmer et al., 2003; O'Rouke et al., 2008). Although no ground beetle species appears to be strictly bound to a certain crop, early agro-ecological studies in Europe reported a general difference between ground beetle abundance distributions in winter cereals versus root crops (Heydemann, 1955). The highest ground beetle abundance on fields 3T (wheat) and 3L (oilseed rape) can be affected by the characteristic of present crop but also can be the result of the specific crop rotation. O'Rourke et al. (2008) stated that thick stand crops, especially those which were sown in autumn, may provide important refuges for ground beetles in comparison with crops which were sown in spring. Wheat and oilseed rape sown at fields $3 \mathrm{~L}$ and $3 \mathrm{~T}$ in our survey confirm the importance of crop habitat for supporting ground beetle populations. These are overwintering crops which provided less extreme microhabitat in spring and created positive conditions for ground beetle survival.

(v) Beside crop specifics (thick stands and seasonal character), which obviously had great influence on abundance, a very long bare soil period can also be a significant factor that affect ground beetles. Our results confirm the statement of Kromp (1999) that very long period of bare soil in spring in sugar beet and maize crops (Table 1) present extreme soil surface microclimate which has a negative influence on ground beetle abundance. In root crops, the long period of bare soil in early spring creates a rather extreme soil-surface microclimate (high temperatures and insolation during the day), which changes with ongoing crop development towards being shadowy and humid. In winter cereals, the less extreme microclimate already established in early spring creates favorable conditions for ground beetles (Komp, 1999). Both locations in our study, where sugar beet was sown, have a period of bare soil for 7 months (0T) and 9 months (0L) which present exceptionally long period without plant cover. The low caches on these fields can be explained with extreme soil surface microclimate as a consequence of long bare soil period.

(vi) Our results shown correlation between plant cover and ground beetle catches since we recorded higher total ground beetle caches per week in winter crops which were sown in autumn previous year, comparing with sugar beet and maize which were sown in spring after long bare soil period.

(vii) Results of this study have also emphasized the influence of fertilization and insecticidal management practices on ground beetles. Generally, the fertilization was more intensive in Lukač, while insecticide treatments were more intensive in Tovarnik. Considering greater ground beetle abundance in Lukač than in Tovarnik our results confirm previous studies where has been concluded that insecticides have negative influence on the ground beetle populations (Asteraki et al., 1992; 1995). For the full conclusion of insecticide influence on ground beetles more detailed investigation should be conducted. Fertilization was considered to decrease ground beetle abundance exclusively when was applied with the high amount of nitrogen as mineral fertilizer (Kromp, 1999). The levels of nitrogen applied in all fields are compatible with permitted levels according to integrated plant production in Croatia (EU Directive 2009/128/EC) which provides minimal negative influence on all beneficial fauna. Organic manure has not been applied at investigated fields so possible positive effect 
(as in: Pietraszko and De Clercq, 1982; Hence and Grégoire-Wibo, 1987) on ground beetles cannot be confirmed.

(viii) At both locations, the crops have been grown in four-year crop rotation. The main focus in our survey was on sugar beet and its rearing in crop rotations on both locations due to the fact that, in Croatia, sugar beet is most intensive culture considering agro-technical measures and pest protection requirements. As it was presented in Table 1 , fields where sugar beet was grown in 2015, underwent the most intensive tillage, fertilization and insecticide treatments (seed treated with neonicotinoids). As presented in Tables 4 and 5, our results shown the lowest ground beetle abundance on the sugar beet fields (0L and 0T) which is in accordance with results of Mullin et al. (2010) and Kos et al. (2013) who demonstrated the negative effect of neonicotinoids applied as a seed treatment on ground beetles. In Vukovar - Sirmium County besides seed treatment, three additional insecticide treatments have been applied on the sugar beet field 0T (Table 1) what may have additional negative influence on ground beetle abundance. Therefore, we estimated that sugar beet cultivation has the greatest negative influence on ground beetle populations but with the assumption that abundance can be restored in the years after sugar beet growing. Indeed in the years after sugar beet (fouryear crop rotation: see detailed in Table 1) the ground beetle abundance increased.

\section{Conclusions}

Intensive agricultural production of arable crops generates different degrees of disturbances in the ground beetle life cycle trough specific environmental and management conditions. Clearly, there is more than just one factor which could significantly change the abundance of ground beetles. Sugar beet cultivation, which implies particularly intensive tillage and insecticide application, reduces ground beetle abundance, whose number recovered after the four-year crop rotation. It is shown that the arable agroecosystems influence the ground beetle community through the modification of environmental conditions (soil characteristics, microclimate factors such as temperature and humidity), as well as through disturbance factors such as tillage schedules and harvest/sowing schedules.

Acknowledgements. We give great gratitude to family farms Katančić, Špoljar, Drmić and Marinković for conceding the fields where the research was conducted. The study was funded by the European Union from the European Social Fund within the project "Improving human capital by professional development through the research program in Plant Medicine," HR.3.2.01-0071.

\section{REFERENCES}

[1] Asteraki, E.J., Hanks, C.B., Clements, R.O. (1992): The impact of two insecticides on predatory ground beetles (Carabidae) in newly-sown grass. - Ann. Appl. Biol. 120(1): 2539.

[2] Asteraki, E.J., Hanks, C.B., Clements, R.O. (1995): The influence of different types of grassland field margin on carabid beetle (Coleoptera: Carabidae) communities. - Agric. Ecosyst. Envir. 54(3): 125-128.

[3] Auber, L. (1965): Atlas des coléoptères de France, Belgique, Suisse. (TOM 1). - Editions N. Boubée, Paris. 
[4] Baguette, M., Hence, T. (1997): Carabid beetle and agricultural practices: influence of soil ploughing. - In: Kromp B., Meindl P. (eds.) Entomological Research in Organic Farming, Biol. Agric. Hortic.

[5] Baranová, B., Fazekašová, D., Jászay, T., Manko, P. (2013): Ground beetle (Coleoptera: Carabidae) community of arable land with different crops. - Folis faunistica Slovaca 18(1): 21-29.

[6] Barbercheck, M.E. (1992): Effect of Soil Physical Factors on Biological Control Agents of Soil Insect Pests. - The Florida Entomologist 75(4): 539-548.

[7] Basedow, T. (1987): Der Einflu $\beta$ gesteigerter Bewirtschaftungs intensität in Getreidebau auf die Laufkäfer (Coleoptera: Carabidae). Milt. Biol. Bundesanst. - Land-Fortwirtsch, Berlin-Dahlem.

[8] Bažok, R., Kos T., Igrc Barčić, J., Kolak, V., Lazarević, B., Čatić, A. (2007): Abundance and distribution of the ground beetles Pterostichus melanarius (Illiger, 1798) and Pseudoophonus rufipes (DeGeer, 1774) in corn fields in Croatia. - Entomologia Croatica 11(1-2): 39-51.

[9] Bechyne, J. (1974): Welcher Käfer ist das? Kosmos - Natürfuhrer, Stuttgart.

[10] Benitez, A.H., Lemić, D., Bažok, R., Gallardo-Araya, C.M., Mikac, K.M. (2014): Evolutionary directional asymmetry and shape variation in Diabrotica virgifera virgifera (Coleoptera: Chrysomelidae): an example using hind wings. - Biological Journal of the Linnean Society 111: 110-118.

[11] Blake, S., Foster, G.N., Fischer, G.E.J., Ligertwood, G.L. (1996): Effects of management practices on the ground beetle faunas of newly established wildflower meadows in southern Scotland. - Annales Zoologici Fennici 33: 139-147.

[12] Blumberg, A.Y., Crossley Jr., D.A. (1983): Comparison of soil surface arthropod populations in conventional tillage, no-tillage and old field systems. - Agro-Ecosystems 8: 247-253.

[13] Cárcamo, H.A. (1995): Effect of tillage on ground beetles (Coleoptera: Carabidae): a farm-scale study in central Alberta. - Can. Entomol. 127: 631-639.

[14] Chapman, A.N. (2014): The Influence of Landscape Heterogeneity - Ground Beetles (Coleoptera: Carabidae) in Fthiotida, Central Greece. - Biodivers Data J. (2): e1082.

[15] Cole, L.J., McCracken, D.I., Dennis, P. (2002): Relationship between agricultural management and ecological groups of ground beetles (Coleoptera, Carabidae) on Scottish farmland. Agric. Ecosyst. - Envir. 93(1-3): 323-336.

[16] Dobrovolsky, B.V. (1970): Biological grounds for plant protection against wireworms in the USSR. - Pedobiologia 10: 26-44.

[17] Douglas, M.R., Rohr, J.R., Tooker, J.F. (2014): Neonicotinoid insecticide travels through a soil food chain, disrupting biological control of non-target pests and decreasing soya bean yield. - Journal of Applied Ecology. doi: 10.1111/1365-2664.12372

[18] Ferguson, H.J., McPherson, R.M. (1985): Abundance and diversity of adult carabidae in four soybean cropping systems in Virginia. - J. Entomol. Sci. 20: 163-171.

[19] Gylling Data Management. (2015): Inc. ARM 9® GDM software, Revision 9.2014.7 January 28, 2015 (B=20741) - Brookings, South Dakota, USA

[20] Harde, K.W., Severa, F. (1984): Der Kosmos Käferführer, Kosmos - Natürfuhrer, Stuttgart.

[21] Hence, T., Grégorie-Wibo, C. (1987): Effect of agricultural practices on carabid populations. - Acta Phytopathol. Entomol. Hung. 22: 147-160.

[22] Hence, T., Grégorie-Wibo, C., Lebrun Ph. (1990): Agriculture and ground-beetle populations. The consequence of crop types and surrounding habitats on activity and species composition. - Pedobiologia 34: 337-346.

[23] Heydemann, B. (1955): Carabiden der Kulturfelder als ökologische. Indikatoren. Ber. 7. Wandervers. dt. Entomologen.

[24] Holland, J.M. (2002): Carabid beetles: their ecology, survival and use in agroecosystems. - In: Holland, J.M. (ed.) The agroecology of Carabid beetles. Intercept, Andover, UK. 
[25] Holland, J.M., Reynolds, C.J.M. (2003): The impact of soil cultivation on arthropod (Coleoptera and Araneae) emergence on arable land. - Pedobiologia 47: 181-191.

[26] Honek, A., Jarosik, V. (2000): The role of crop density, seed and aphid presence in diversification of field communities of Carabidae (Coleoptera). - Eur. J. Entomol. 97: 517-525.

[27] Hong, L., Futch, S.H., Stuart, R.J., Syvertsen, J.P., McCoy, C.W. (2007): Associations of soil iron with citrus tree decline and variability of sand, soil water, $\mathrm{pH}$, magnesium and Diaprepes abbreviatus root weevil: Two-site study. - Environmental and Experimental Botany 59(3): 321-333.

[28] House, G.J., All, N.J. (1981): Carabid beetles in soybean agroecosystems. - Environ. Entomol. 10: 194-196.

[29] House, G.J., Parmalee, R.W. (1985): Comparison of soil arthropods and earthworms from conventional and no-tillage agroecosystems. - Soil Tillage Res. 5: 351-360.

[30] House, G.J., Stinner, B.R. (1983): Arthropods in no-tillage soybean agroecosystems: community composition and ecosystem interactions. - Environ. Manage. 7: 23-28.

[31] Jeschke, P., Nauen, R., Schnidler, M., Elbert, A. (2011): Overview of the status and global strategy for neonicotinoids. - Journal of Agricultural and Food Chemistry 59: 2897-2908.

[32] Kisić, I., Bašić, F., Butorac, A., Mesić, M., Nestroy, O., Sabolić, M. (2005): Erozija tla vodom pri različitim načinima obrade. - AKD d.o.o., Zagreb

[33] Kos, T., Bažok, R., Drmić, Z., Graša, Ž. (2013): Ground beetles (Coleoptera: Carabidae) in sugar beet fields as the base for conservation biological control. - Insect Pathogens and Entomoparasitic Nematodes" Biological Control- its unique role in integrated and organic production. IOBC-WPRS Bulletin 90: 353-357.

[34] Kos, T., Bažok, R., Igrc Barčić, J. (2011): Abundance and frequency of ground beetles in three maize fields in Croatia. - Journal of Environmental Protection and Ecology. 12(3): 894-902.

[35] Kos, T., Bažok, R., Kozina, A., Šipraga, J., Dragić, S., Tičinović, A. (2010): Ground beetle (Carabidae) fauna at untreated and treated barley fields in Croatia. - Pesticides and Beneficial Organisms IOBC/wprs Bulletin 55: 79-84.

[36] Kozina, A., Lemic, D., Bažok, R., Mikac, K.M., Mclean, C.M., Ivezić, M., Igrc Barčić, J. (2015): Climatic, Edaphic Factors and Cropping History Help Predict Click Beetle Coleoptera: Elateridae) (Agriotes spp.) Abundance. - Journal of Insect Science 15(1): 100 .

[37] Kromp, B. (1999): Carabid beetles in sustainable agriculture: a review on pest control efficacy, cultivation impacts and enhancement. - Agric. Ecosyst. Environ. 74: 187-228

[38] Lövei, G.L. (1984): Ground beetles (Coleoptera: Carabidae) in two types of maize fields in Hungary. - Pedobiologia 26: 57-64.

[39] Lövei, G.L., Sunderland, K.D. (1996): Ecology and behavior of ground beetles (Coleoptera: Carabidae). - Annu. Rev. Entomol. 41: 231-236.

[40] Maelfait, J. P., Desender, K. (1990): Possibilities of Short-term Carabid Sampling for Site Assessment Studies. - In: Stork, N.E.(ed.) The role of Ground Beetles in Ecological and Environmental Studies. Intercept, Andower.

[41] Meissner, R.L. (1984): Zur Biologie und Ökologie der ripicolen Carabiden Bembidion femoratum Sturm und B. punctulatum Drap. II. Die Substratbindung. - Zool. Jb. Syst. 111: 369-383.

[42] Mullin, C.A., Frazier, M., Frazier, J.L., Ashcraft, S., Simonds, R., van Engelsdorp D., Pettis, J.S. (2010): High levels of miticides and agrochemicals in North American apiaries: implications for honey bee health. - PlosOne 5:e9754

[43] Niemelä, J., Halme, E., Haila, Y. (1990): Balancing sampling effort in pitfall trapping of carabid beetle. - Entomol. Fennica 1: 233-238. 
[44] O'Rourke, M.E., Liebman, M., Rice, M.E. (2008): Ground beetle (Coleoptera: Carabidae) assemblage in conventional and diversified crop rotation systems. - Environ. Entomol. 37(1): 121-130.

[45] Östman, Ö., Ekbom, B., Bengtsson, J., Weibull, A. (2001): Landscape Complexity and Farming Practice Influence the Condition of Polyphagous Carabid Beetles. - Ecological Applications. 11: 480-488.

[46] Penzar, I., Penzar, B. (2000): Agrometeorologija. - Školska knjiga, Zagreb.

[47] Pietraszko, R., De Clercq, R. (1982): Influence of organic matter on epigeic arthropods. Med. Fac. Landbouww. Rijksuniv. Gent. 47(2): 721-728.

[48] Pollard, E. (1968): Hedges, III. The Effect of Removal of the Bottom Flora of a Hawthorn Hedge on the Carabidae of the Hedge Bottom. - Journal of Applied Ecology. 5: 125-139.

[49] Raino, J., Niemelä, J. (2003): Ground beetles (Coleoptera: Carabidae) as bioindicators. Biodiversity \& Conservation. 12(3): 487-506.

[50] Sotherton, N. (1985): The Distribution and Abundance of Predatory Coleoptera Overwintering in Field Boundaries. - Annals of Applied Biology. 106: 17-21.

[51] Stassart, P., Grégorie-Wibo, C. (1983): Influence du travail du sol sur les populations de carabides en grande culture, resultats preliminaires. - Med. Fac. Landbouww. Rijksuniv. Gent 48(2): 465-474.

[52] Stinner, B.R., McCartney, D.A., Van Doren Jr., D.M. (1988): Soil and foliage arthropod communities in conventional, reduced and no-tillage corn (maize, Zea mays, L.) systems: a comparison after 20 years of continuous cropping. - Soil Tillage Res. 11: 147-158.

[53] Szczepaniec, A., Creary, S.F., Laskowski, K.L., Nyrop, J.P., Raupp, M.J. (2011): Neonicotinoid insecticide imidacloprid causes outbreaks of spider mites on elm trees in urban landscapes. - PlosOne 6: e20018

[54] Thiele, H.U. (1977): Carabid beetles in their Environment: a Study on Habitat Selection by Adaptations in Physiology and Behaviour. - Springer, Berlin.

[55] Tonhasca, A. (1993): Carabid beetle assemblage under diversified agroecosystems. Entomol. Exp. Appl. 68: 279-285.

[56] Turpin, F.T., Peters, D.C. (1971): Survival of Southern and Western Corn Rootworm Larvae in Relation to Soil Texture. - Jounal of Economic Entomology DOI: http://dx.doi.org/10.1093/jee/64.6.1448

[57] Varvara, M., Chimisliu, C., Šustek, Z. (2012): Distribution and abundance of Calosoma uropunctatum Herbst 1784. (Coleoptera: Carabidae) in some agricultural crops in Romania, 1977-2010. Oltenia. Studii și comunicări. - Ştiinșele Naturii 28(1): 79-90.

[58] Vician, V., Svitok, M., Kočik, K., Stašiov, S. (2015): The influence of agricultural management on the structure of ground beetle (Coleoptera: Carabidae) assemblages. Biologia 70(2): 240-251

[59] Ward, K.E., Ward, R.N. (2001): Diversity and abundance of carabid beetles in shortrotation plantings of sweet-gum, maize and switchgrass in Alabama. - Agrofor. Syst. 53: 261-267.

[60] Weibull, A.C., Östman, Ö., Granquvist, A. (2003): Species richness in agroecosystems: The effect of landscape, habitat and farm management. - Biodivers. Conserv. 12(7): $1335-1355$.

[61] Witmer, J.E., Hough-Goldstein, F.A., Pesek, J.D. (2003): Ground-dwelling and foliar arthropods in four cropping systems. - Environ. Entomol. 32: 366-376.

[62] Zhang, J.X., Drummond, F.A., Liebman, M. (1998): Effect of crop habitat and potato management practices on the population abundance of adult Harpalus rufipes (Coleoptera: Carabidae) in Maine. - J. Agric. Entomol. 15: 63-74. 